\title{
RESPONSABILIDAD DEL ESTADO POR HECHOS DE SUS CONTRATANTES EN EL DERECHO CHILENO
}

\author{
VICARIOUS LIABILITY OF THE STATE FOR ACTIONS OF HIS \\ COUNTERPARTS OF PUBLIC CONTRACTS IN CHILEAN LAW
}

JOSÉ MIGUEL VALDIVIA OLIVARES*

\section{RESUMEN}

Ante la escasez de análisis sobre la responsabilidad pública, algunos han creído que el Estado es responsable por el hecho de sus cocontratantes, sin distinción, incluidos sus concesionarios. Una revisión de la jurisprudencia permite apreciar que la categoría "contraparte contractual" de la administración está lejos de ser uniforme. El estudio sugiere que, al contrario, pueden vislumbrarse al menos cuatro regímenes distintos de responsabilidad.

Palabras clave: Responsabilidad del Estado, Responsabilidad por hecho ajeno, Contratistas, Concesionarios, Contratos administrativos, Derecho administrativo.

* Abogado, Licenciado en Derecho, Universidad de Chile. Doctor en Derecho por la Universidad Paris II, Panthéon-Assas. Profesor de Derecho Administrativo. Investigador del Centro de Regulación y Competencia de la Facultad de Derecho de la Universidad de Chile, Santiago, Chile. Correo electrónico: jmvaldivia@derecho.uchile.cl. ORCID: http://orcid.org/0000-0002-7556-2951.

Trabajo recibido el 7 de septiembre de 2020, y aceptado para su publicación el 16 de junio de 2021. 


\section{ABSTRACT}

In a context of lack of studies on State liability in Chilean law, some have said that State must be vicariously responsible for the actions of his counterparts in all kinds of public contracts. The case law shows that the category of "contractual counterpart" of the public administration doesn't have uniformity. On the contrary, this study suggests that at least four systems of liability can be noticed on this field.

Keywords: State liability, Vicarious liability, Contractors, Concessionaries, Administrative contracts, Administrative law.

\section{INTRODUCCIÓN}

En un reciente fallo, Santander Flores, puede leerse a la Corte Suprema decir que "la doctrina y la jurisprudencia es conteste en que la Administración debe responder por los daños ocasionados por contratistas y/o concesionarios en virtud de la responsabilidad in vigilando". ${ }^{1}$ A diferencia de lo que sostiene la Corte, en el derecho positivo chileno hay muy poca claridad respecto de la responsabilidad que podría incumbir a la administración (el Estado y demás personas públicas) por los hechos dañosos de personas o empresas contratadas por ella para el cumplimiento de sus misiones.

La experienciajudicial en este tipo de casos es magra y lamentablemente bastante desordenada. Solo a propósito de la responsabilidad del Estado por hechos de los concesionarios de obras públicas viales han surgido cuestiones con cierta recurrencia en el último tiempo, pero la jurisprudencia está lejos de haberse uniformado al respecto. A esta relativa incertidumbre se suma la escasa producción doctrinal sobre este punto. ${ }^{2}$

Ahora bien, más allá de estos déficits, es legítimo preguntarse si cabe distinguir en el seno de la responsabilidad una categoría única en relación con las contrapartes contractuales de la administración, como sugiere

${ }^{1}$ Corte Suprema, 22 de mayo de 2017, Rol N 4.860-2017 (cons. 6). Idéntica consideración en Corte Suprema, 25 de mayo de 2017, Rol N ${ }^{\circ} 55.177-2016$ (cons. 8).

${ }^{2} C f r$. la doctrina citada en n. 59. 
la sentencia mencionada. No se trata aquí de negar la sustantividad de la noción de contrato (de la administración o administrativo), sino de su pertinencia como género al interior de las preguntas típicas que hace surgir la responsabilidad del Estado: usualmente esta depende de los deberes de la administración, que carecen de uniformidad en el ámbito contractual.

Elpresenteestudiose proponedesafiareseentendimiento aparentemente gratuito de Santander Flores, analizando el derecho administrativo chileno de la responsabilidad por falta de servicio, con sustento en la jurisprudencia.

El análisis se efectúa en dos tiempos. Primero se intenta identificar los intereses materiales que están en juego en este terreno, con el fin de comprender las orientaciones que se advierten en el derecho positivo. En segundo lugar, se pasa revista a las soluciones jurisprudenciales, a la luz de las situaciones contractuales que pueden dar lugar a este tipo de problemas. $\mathrm{Al}$ efecto se propone un orden que atiende a los tipos contractuales más comunes en el derecho administrativo chileno, en función del grado de autonomía del cocontratante de la administración, en tanto pueda tener proyección en el campo de la responsabilidad extracontractual.

\section{INTERESES EN JUEGO}

En algún grado, la dificultad de la búsqueda de soluciones en este campo se debe a la presencia típica de (al menos) tres protagonistas: por una parte, la víctima y, por la otra, el hechor y la administración, que mediante una operación contractual ha puesto a aquel en contacto con la víctima. Si teóricamente el interés de la víctima es fácil de discernir, no ocurre lo mismo con el de los posibles responsables, que en estos casos se presentan separados al menos en dos, quienes frecuentemente intentan achacarse recíprocamente la responsabilidad.

\section{El interés de la víctima}

El interés de la víctima es aparentemente predominante en la construcción de los sistemas de responsabilidad. La víctima es siempre un protagonista de la responsabilidad extracontractual, en cuanto ésta procura precisamente la indemnización de sus perjuicios (cuando puedan tenerse por injustamente causados o sufridos). Se repite corrientemente desde el derecho 
privado que el interés de la víctima ha sido el motor de la responsabilidad y sus fluctuaciones jurisprudenciales a todo lo largo del último siglo. ${ }^{3}$ Esa influencia también se deja sentir en la responsabilidad pública.

En la situación puntual que aquí interesa, la preocupación por la víctima adquiere un relieve singular. En efecto, la pluralidad de candidatos a ser demandados puede ser fuente de riesgos; de no enderezar correctamente la demanda -esto es, contra aquel que el derecho designa como responsablela víctima podría ver defraudada su legítima expectativa de obtener reparación. Ahora bien, esa expectativa puede enfrentarse a las de los potenciales responsables unidos por medio de un contrato. En principio, todo contrato comporta un arbitraje de riesgos entre los contratantes; y el riesgo de los perjuicios asociados es usualmente uno de aquellos que las partes se esfuerzan por distribuir entre sí. Con todo, es difícil dar a esos pactos (res inter alios) un alcance tal que defraude los intereses de la víctima al impedir el juego normal de las reglas de responsabilidad. El contrato -ni a fortiori el subcontrato- no puede ser tenido como herramienta de elusión de la responsabilidad.

\section{Interés, en especial, de los trabajadores}

El terreno en el que esta tendencia ha tenido mayor repercusión práctica ha sido el de los accidentes del trabajo, en razón de la simpatía de la legislación contemporánea por los trabajadores como sujetos dignos de protección.

Conforme a reglas antiguas, el derecho positivo contempla un régimen de reparación automática a cargo de un seguro obligatorio cuya prima financia el empleador (Ley 16.744, sobre accidentes del trabajo y enfermedades profesionales), sumado a una obligación de seguridad también puesta a cargo del empleador (Código del Trabajo, art. 184). La operatividad de esta última obligación se aprecia sobre todo en caso de pretenderse una indemnización completa de los perjuicios (esto es, suplementaria de la indemnización cubierta por el seguro obligatorio - Ley 16.744, art. 69).

La Ley 20.123, de 2006, que regula el trabajo en régimen de subcontratación, extiende la obligación de seguridad también al "dueño de la

\footnotetext{
${ }^{3}$ Entre una muy abundante literatura, v. Chabas, François, Cien años de responsabilidad civil en Francia, Van Dieren éditeur, París, 2004, (trad. Mauricio TAPIA).
} 
obra" (regla contenida en el Código del Trabajo, art. 183 E). El objetivo de la regla era impedir que el recurso a la subcontratación prive a los trabajadores de un patrimonio responsable suficientemente cuantioso como para hacer frente a eventuales condenas pecuniarias que surgieren. El resultado (aparte de un posible incremento material en las condiciones de seguridad de las faenas), consiste en que el trabajador dispone al menos de dos candidatos a ser juzgados responsables, a quienes podría demandar. La ley no ha contemplado una garantía solidaria para este supuesto, pero algún autor ha puesto en evidencia que el dispositivo legal mismo supone una obligación in solidum, de efectos análogos frente a la víctima. ${ }^{4}$ Naturalmente, este mecanismo tiende a reemplazar a la antigua responsabilidad subsidiaria del dueño de la obra, contemplada en el derogado artículo 64 del Código.

Para lo que aquí interesa, la jurisprudencia no ha visto inconveniente en que los organismos públicos contratantes sean considerados como empresas principales, ${ }^{5}$ en tanto dueños de las obras respectivas, ${ }^{6} \mathrm{y}$, por lo tanto, hacerles extensivo este último mecanismo de responsabilidad. Los organismos públicos contratantes se entienden, pues, obligados también a adoptar medidas de seguridad en relación con los trabajadores en régimen de subcontratación. Por cierto, el establecimiento de tal obligación de seguridad resulta consistente con el régimen de responsabilidad por falta de servicio, pues el incumplimiento de esa obligación puede ser concebido como una falta de servicio. De aquí que, no obstante su especialidad, las soluciones propias de este ámbito también quepan en el marco de la teoría general de la responsabilidad pública.

Ahora bien, más allá de los problemas específicos del campo de los accidentes del trabajo, una preocupación similar por no burlar las expectativas de la víctima conduce, en el derecho comparado, a ofrecer a ésta el mayor número de opciones posible en presencia de multiplicidad de eventuales responsables. Sin duda esa influencia se deja sentir en el derecho chileno.

\footnotetext{
${ }^{4}$ CORRAL, Hernán, "Subcontratación y responsabilidad civil por accidentes del trabajo", 2014, https:// www.elmercurio.com/Legal/Noticias/Analisis-Juridico/2014/08/11/Subcontratacion-y-responsabilidadcivil-por-accidentes-del-trabajo.aspx, consultada: 24 de agosto de 2020.

${ }^{5}$ Contraloría General de la República, 21 de enero de 2008, Dictamen N².594.

${ }^{6}$ P. ej., Corte Suprema, 21 de agosto de 2017, Rol No 92.863-2016 o, más recientemente, Corte Suprema, 8 de abril de 2019, Rol № 5.393-2018. En cambio, si el órgano público no es dueño de la obra y se limita a prestar asistencia técnica a terceros, no procede su responsabilidad: Corte Suprema, 17 de abril de 2020, Rol N²4.675-2018.
} 


\section{El interés de los eventuales responsables}

Desde la perspectiva de los posibles responsables, las preocupaciones son completamente opuestas. Lo común en supuestos de litigios es que la administración, demandada en un juicio de responsabilidad, busque escudarse en la intervención de un tercero (el contratista) en el origen del daño. Puede asumirse, a su vez, que el contratista demandado perseguirá minimizar al máximo el riesgo de una condena pecuniaria. En buena medida, esta diferencia de posición estratégica ha de enfrentarse por medio del principio de responsabilidad individual.

En el derecho privado, el carácter individual de la responsabilidad extracontractual es difícilmente controvertible. La responsabilidad civil es, en buena medida, correlato de la condición de persona libre y consciente. Por eso, cada uno es responsable de sus propios actos. Inversamente, las responsabilidades por hecho ajeno son excepcionales y sólo surgen ahí donde hay buenas razones para asumir suficiente grado de control del tercero civilmente responsable sobre el autor material de los daños. En el caso chileno, el control que justifica la responsabilidad extracontractual por hecho ajeno se entiende configurado fundamentalmente al interior de relaciones familiares en el caso de los padres respecto de sus hijos menores, así como en el ámbito de las relaciones de trabajo, domésticas o de otro orden, en el que los empresarios o, extensivamente, empleadores ejercen respecto de sus dependientes (Código Civil, art. 2320). ${ }^{7}$

La lógica del derecho privado no es extrapolable sin más al derecho público, en que la responsabilidad queda regida por sus propios criterios. La responsabilidad del Estado no contempla mecanismos de responsabilidad por hecho ajeno distintos de los que pudieran tener lugar al interior de la estructura orgánica del aparato estatal. ${ }^{8}$ La noción jurídica de falta de servicio, no obstante absorber el comportamiento habitual de los agentes públicos (incluyendo su negligencia habitual), opera en la práctica como una responsabilidad por hecho propio de la administración; en cambio, la responsabilidad que incumba al Estado por la falta personal de sus agentes

\footnotetext{
${ }^{7}$ Sobre la materia, v. BARros, Enrique, Tratado de responsabilidad extracontractual, Editorial Jurídica de Chile, Santiago, 2006, p. 167 y s.

${ }^{8}$ Esta materia es analizada, en parte, en VAldivia, José Miguel, “Teoría del órgano y responsabilidad pública en la Ley de Bases de la Administración del Estado", Revista de Derecho (Valdivia), 2006, N 19 , p. 133 y ss.
} 
- especialmente en caso de que no concurra además una falta de servicio9podría entenderse que opera como una responsabilidad por hecho ajeno, de aplicación práctica relativamente marginal. Más allá de estos casos, el derecho administrativo chileno no contempla nada parecido a una responsabilidad por hecho ajeno. ${ }^{10}$ En principio, pues, el Estado no está llamado a responder por el hecho de sus contratantes privados.

Por cierto, el principio privatista de la responsabilidad individual rige también ahí donde confluyen algunos agentes privados e instituciones estatales: la presencia del Estado en las inmediaciones del daño no excluye la responsabilidad de los particulares concurrentes. En otros términos, la eventual responsabilidad del Estado no tiene por efecto suprimir ni desplazar la responsabilidad civil individual de esos particulares, por muy vinculados que estén al Estado por medio de contratos. A fin de cuentas, la responsabilidad pública no es un mecanismo de absorción de responsabilidades privadas.

\section{EL PRINCIPIO DE RESPONSABILIDAD INDIVIDUAL}

\section{Su recepción jurisprudencial}

La vigencia de este principio ha sido afirmada recientemente en un fallo Pastelería Arraya. En el caso se perseguía la responsabilidad de la municipalidad de Talcahuano a raíz de los daños provocados por un contratista encargado de unas obras. ${ }^{11}$ La Corte Suprema sostiene, con fundamento en principios tradicionales del derecho civil, que no puede estimarse

\footnotetext{
${ }^{9}$ Es el caso del muy conocido fallo de la Corte Suprema, 14 de enero de 2011, Rol No 7.919-2008 (responsabilidad del Estado por el disparo intencional de un carabinero sobre un compañero de labores, fuera del horario de trabajo pero dentro del recinto público en que están obligados a residir). Bajo una fórmula de fuerte resonancia francesa, la Corte justifica la responsabilidad pública en razón de una falta personal no desprovista de todo vínculo con el servicio. Por lo demás, la Corte Suprema funda la decisión explícitamente en el artículo 2320 del Código Civil, en relación con la responsabilidad civil del empresario por hecho de su dependiente. Cfr. comentario de Valdivia, José Miguel, "Derecho administrativo", Revista de Derecho U. Adolfo Ibáñez, 2015, N 4, p. 549 y s. (específicamente, p. 616 y s.)

${ }^{10}$ Para el derecho francés, una conclusión análoga en Delvolvé, Pierre, "La responsabilité du fait d'autrui en droit administratif', en Université des sciences sociales de Toulouse (Eds.), Mélanges dédiés à Gabriel Marty, Presses de l'Université de Sciences sociales de Toulouse, Toulouse, 1978, p. 407 y ss.

${ }^{11}$ Corte Suprema, 12 de abril de 2016, Rol №37.438-2015.
} 
al contratista como "dependiente" de la municipalidad. El contratista, titular de un contrato celebrado con la municipalidad en ejercicio de sus atribuciones, "no resulta alguien que se encuentre al cuidado municipal, sino un contratante que, habiendo demostrado los conocimientos y aptitudes técnicas necesarias para la realización de las obras, asume derechos y obligaciones propios" (cons. 12). En consecuencia, la falta de servicio del municipio "no puede extraerse pura y simplemente de la responsabilidad de un tercero sin previamente acreditar la culpa del servicio" (cons. 13). El fallo Pastelería Arraya sienta como principio que la administración no es responsable de las culpas de sus contratantes, sino sólo de las suyas propias.

A la luz de este entendimiento, no se aprecia muy bien la justificación de aquellos otros planteamientos que pretenden asignar al Estado el papel de "garante" de sus colaboradores. ${ }^{12}$ Parece más consistente con los principios mejor asentados el reconocimiento de San Martín Muñoz, conforme al cual la responsabilidad del Estado "sólo puede ser declarada a virtud de un incumplimiento de las obligaciones propias y particulares que la ley le ha impuesto sobre la materia, y no como garante de las obligaciones que ha debido cumplir" su contraparte. ${ }^{13}$

\section{Contribución a la deuda y responsabilidad individual}

Es indudable que el principio de la responsabilidad individual recorre los mecanismos de restitución que normalmente tienen lugar a raíz de la repartición definitiva del peso de una obligación indemnizatoria entre varios obligados. Ha de admitirse que, salvo que el contrato haya dispuesto algo distinto, en principio la administración contratante tiene derecho a recuperar las sumas de dinero que haya debido desembolsar para cubrir las culpas de su cocontratante (ya sea con fundamento en el contrato, en la responsabilidad extracontractual, en el pago de lo no debido o en el enriquecimiento sin

\footnotetext{
${ }^{12}$ P. ej., en Torres González (Corte Suprema, 21 de agosto de 2017, cit.) se afirma que "el Estado, al delegar funciones o encargar la realización de una obra, como ocurre en la especie, permanece como garante, de conformidad con los estándares que le son exigibles, de la prestación de un servicio que ha sido delegada" (sentencia de reemplazo, cons. 8). Inicialmente, la expresión proviene de una prevención minoritaria del ministro Sergio Muñoz y del abogado integrante Jorge Baraona en Corte Suprema, 5 de noviembre de 2013, Rol $N^{\circ}$ 9.163-2012, quienes a su vez parecen haberla tomado del tratado de BARROS, cit. (n. 7), p. 530.

${ }^{13}$ Corte Suprema, 1 de junio de 2012, Rol N 6.867-2011 (cons. 11). En el caso se discute la responsabilidad pública por accidentes del trabajo.
} 
causa). Sin embargo, por sí solos, los mecanismos de repetición no ofrecen ninguna justificación para el establecimiento de la deuda misma. En otras palabras, en los casos que aquí interesan, la responsabilidad del Estado tampoco puede inferirse de la sola eventualidad de aplicación de mecanismos de repetición entre la administración y sus contratantes (como es frecuente que se establezcan por medio de contratos).

La repetición sólojuega en el plano de la "contribución a la deuda" (esto es, la repartición definitiva del peso de la reparación) y no tiene incidencia en el de la "obligación a la deuda" (que concierne al aseguramiento provisorio de la obligación frente al acreedor, que en este caso es la víctima). Que alguien disponga de una acción en contra del deudor definitivo de una obligación no justifica que sea tenido por responsable frente a la víctima; de ser así, cualquier persona podría ser llamada a responder de las deudas de otro, diluyéndose por completo el sentido de las obligaciones. En este sentido, un planteamiento como el de Pastelería Arraya provee una base justificativa más sólida para la indemnización: sólo quien haya incurrido en culpas propias puede ser perseguido por la víctima.

\section{FALTA DE SERVICIO EN EL CONTEXTO DE CONTRATOS ADMI- NISTRATIVOS}

Atendida la importancia de la definición de los ámbitos de responsabilidad propia de cada contratante, resulta pertinente cuestionarse acerca del sentido de la responsabilidad del Estado por falta de servicio o, mejor, en qué consiste la culpa del Estado. Mientras más amplia sea esa noción, por ejemplo, como correlativa a las misiones o metas del Estado, más sencillo es imputar a la administración los hechos de aquellos particulares que han sido asociados al desarrollo de tales misiones. En cambio, mientras más estricta sea la noción de culpa, vinculada a deberes precisos del Estado, más exigentes serán las condiciones para que éste absorba o asuma las culpas de los privados que trabajan por cuenta de él de un modo más o menos indirecto.

Con buenas razones, la jurisprudencia ha abrazado esta última concepción, ${ }^{14}$ aunque no haya sacado todas las consecuencias que derivarían

\footnotetext{
${ }^{14}$ Por ejemplo, en Osses Mathinson c/ M. Quillón (Corte Suprema, 28 de diciembre de 2012, Rol N ${ }^{\circ}$
} 
de ella en la materia que aquí interesa. La falta de servicio debe construirse a partir de la transgresión de deberes específicos, sin que pueda tenérsela por equivalente a la frustración de las metas estatales (como ocurriría en caso de estimarse defraudado un objetivo de seguridad pública a raíz de la comisión de delitos por terceros). ${ }^{15}$

A partir de esta premisa, parece razonable pensar que, si la responsabilidad por falta de servicio sólo recubre el incumplimiento de deberes específicos de la administración, aparezca predominantemente en aquellas situaciones contractuales que confieren a ésta un protagonismo mayor, e inversamente, que su reconocimiento sea más difícil en aquellas relaciones contractuales que confieren al contratante de la administración un ámbito de autonomía más significativo. Por lo mismo, resulta cuestionable asumir que la responsabilidad del Estado cubra, en razón de las misiones superiores del Estado respecto de cierto ámbito de materias, cualquier accidente ocurrido en ese campo y que sea imputable a sus contratantes. Por cierto, más allá de esas conclusiones generales conviene prestar atención a las distintas situaciones de hecho que pudieren presentarse.

\section{LA RESPONSABILIDAD DEL ESTADO EN LOS DISTINTOS CONTRA- TOS ADMINISTRATIVOS}

Los criterios recién expuestos sugieren que la determinación de la responsabilidad que pudiera incumbir al Estado en estos supuestos está en función del nivel de la autonomía con que el cocontratante de la administración cuenta en la ejecución de sus obligaciones. ${ }^{16}$ Por eso, es útil revisar el estado de las cuestiones a la luz de la estructura relacional de los tipos contractuales más frecuentes en el derecho administrativo. Para estos efectos se distinguirán los contratos en dos grandes grupos: contratos de intercambio (en los que la administración recibe una prestación a cambio de otra, normalmente una suma de dinero) y concesiones (en que el

10.614-2011) la Corte Suprema descarta fundar la responsabilidad en la frustración de las misiones del servicio público para justificarla en la transgresión de deberes.

${ }^{15}$ Corte Suprema, 19 de enero de 2010, Rol N 3.172-2008.

${ }^{16}$ Sobre la variabilidad del control de la administración sobre su cocontratante, v. DE LAUBADĖRE, André; Moderne, Franck; Delvolvé, Pierre, Traité des Contrats Administratif, LGDJ, Paris, 1983, $2^{\mathrm{a}}$ éd., T. II, p. $383 \mathrm{~s}$. 
contratante de la administración asume una tarea administrativa, sin mediar contraprestación de esta). ${ }^{17}$

\section{Contratos de intercambio}

La gran mayoría de contratos en que participa la administración tiene por objeto la adquisición de bienes o la obtención de servicios a cambio de una contraprestación normalmente dineraria. Algunos de estos contratos representan intercambios inmediatos, pero otros dan origen a relaciones que se prolongan por periodos breves o extendidos, a lo largo de los cuales pueden surgir problemas de responsabilidad.

Por la función que cumplen, se distinguirá en lo sucesivo aquellos contratos cuyo objeto es el despliegue de una conducta de aquellos que se traducen en la obtención de un resultado.

\section{Contratos de prestación de servicios para la administración}

La jurisprudencia permite separar los contratos de servicios permanentes de aquellos que se prestan esporádicamente.

\subsection{Contratos de prestación de servicios personales de carácter permanente}

Ante todo, conviene analizar la situación de los contratos de prestación de servicios personales que dan origen a una vinculación permanente entre una persona y la administración, funcionalmente equivalente a la que surge mediante relaciones funcionariales plenas. ${ }^{18}$ En el contexto chileno, la cuestión es cuantitativamente importante porque, apartándose del modelo

\footnotetext{
${ }^{17}$ No se ha incluido en el análisis el caso de los convenios suscritos entre el Servicio Nacional de Menores y aquellos que la ley designa como sus colaboradores. A pesar de las apariencias que derivan de esa terminología, la relación corresponde a un régimen de subvenciones más que a un genuino contrato. Para un caso de responsabilidad del Estado perseguida con fundamento en una falta de vigilancia, pero descartada, Corte Suprema, 19 de junio de 2013, Rol № 3.848-2012.

${ }^{18}$ V., en general, Mendoza, Ramiro; Aguerrea, Pedro, "El contrato a honorarios dentro de la administración del Estado, bajo la luz dictaminante de la Contraloría General de la República", en: Contraloría General de la República, La Contraloría General de la República y el estado de derecho. 75 años de vida institucional (1927-2002), Contraloría General de la República, Santiago, 2002, p. 213 y ss.
} 
legal del empleo público, ${ }^{19}$ en las últimas décadas el legislador ha autorizado sistemáticamente a la administración para reclutar personal sobre la base de contratos "a honorarios". ${ }^{20}$

Aun sin estar unidos a la administración mediante vínculos funcionariales, la apariencia fáctica indica que estos agentes son parte del aparato administrativo: ocupan espacio físico en sus oficinas, desarrollan sus servicios en un arco de tiempo equivalente a una jornada de trabajo, participan cotidianamente en las actividades del servicio como la generalidad de los funcionarios. Materialmente, los actos de los funcionarios y los de los prestadores contractuales son difícilmente distinguibles.

Ahora bien, esas condiciones son las mismas que posibilitan la imputación de las culpas institucionales (i.e., las faltas de servicio) a la persona pública de que se trate. ${ }^{21}$ En general, el concepto de falta de servicio identifica a aquella falta que puede ser atribuida directamente al servicio, como por ejemplo la mala organización o el funcionamiento deficiente de la institución, entendida como un complejo orgánico (integrado por bienes, recursos financieros y agentes). Dado que en estos casos la modalidad de funcionamiento del organismo público supone recurrir a prestadores contractuales no funcionarios, la falta de servicio engloba también el comportamiento de estos agentes. La equivalencia entre la falta y la "culpa del servicio" lleva consigo que se imputen a esa abstracción designada como "el servicio" el comportamiento de agentes anónimos que actúan por él, ${ }^{22}$ incluidos los agentes contractuales destinados permanentemente al cumplimiento de las misiones del servicio.

\footnotetext{
${ }^{19}$ RAJeVIC, Enrique, "La precarización del empleo público en Chile y el mito de la carrera funcionaria", Ponencia presentada en el $5^{\circ}$ Encuentro Anual de la Sociedad Chilena de Políticas Públicas, 2014, http://www.academia.edu/5786149/La_precarización_del_empleo_público_en_Chile_y_el_mito_de_ la_carrera_funcionaria, consultada: 24 de agosto de $\overline{2020 .}$.

${ }^{20}$ La expresión (recogida por la ley como "contrato sobre la base de honorarios" — $c f$. Estatuto Administrativo, art. 11) alude a la denominación tradicional de la remuneración típica en contratos de prestación de servicios.

${ }^{21}$ Así describía Hauriou los dos criterios fundamentales en materia de responsabilidad por culpa: por una parte, "el órgano susceptible de comprometer a la Administración es el servicio público, entendido como organismo complejo, compuesto de autoridades, de agentes, de reglamentos y de prácticas administrativas, dedicado al cumplimiento de cierta función"; por otra, la responsabilidad del servicio se ve comprometida "por la culpa de un agente del servicio, cuando esa culpa sólo constituye un hecho de servicio, es decir, entra en las prácticas del servicio, aunque pueda consistir en un error, una imprudencia, una omisión o una negligencia". Hauriou, Maurice, Précis de droit administratif et de droit public, Sirey, París, 1933, 12a ed. (reimpreso por Dalloz en 2002), p. 517.

${ }^{22}$ Así, entre varios, Corte Suprema, 30 de julio de 2009, Rol N 371-2008 (cons. 15).
} 
Por otra parte, y a pesar de una antigua perspectiva doctrinal que buscaba justificar la responsabilidad en la teoría del órgano, la jurisprudencia chilena en materia de responsabilidad nunca ha sido muy rigurosa en la apreciación de la naturaleza del vínculo que une al Estado con sus agentes. ${ }^{23}$ Esa flexibilidad puede llevar a pensar que también los prestadores contractuales de servicios comprometen la responsabilidad de la administración en condiciones análogas a los funcionarios. Adviértase que en el terreno vecino de la responsabilidad civil del empresario por hecho de sus dependientes la jurisprudencia no limita la responsabilidad a las relaciones laborales marcadas por el sello de la subordinación (esto es, un contrato de trabajo), sino que adopta una lectura extensiva de la idea de dependencia; ${ }^{24}$ en buenas cuentas, el personal a honorarios sería "dependiente" de su contraparte para efectos de la responsabilidad civil. ${ }^{25}$ No se entendería muy bien que el derecho administrativo consagrase una solución distinta, y dejase a la víctima entregada a la condición pecuniaria del prestador de servicios para efectos de indemnización.

En estas condiciones, no hay muy buenas razones para asignar a las culpas de estos prestadores contractuales de servicios un trato distinto del que corresponde a las faltas de genuinos funcionarios públicos. Si la culpa se comete en el ejercicio de las tareas encomendadas al prestador, que corresponden grosso modo a funciones administrativas, debería ser calificada como una falta de servicio. ${ }^{26}$ Ahora bien, si se trata de una falta personal la respuesta podría ser distinta: ¿procede que el Estado responda de la culpa propia de un prestador contractual de servicios, en ausencia de toda falta de servicio? En el reciente fallo Fuentes Pino la Corte Suprema ha resuelto

\footnotetext{
${ }^{23}$ Cf. nota 8 .

${ }^{24}$ Barros, cit. (n. 7), p. 185.

${ }^{25}$ BARros, cit. (n. 7), p. 690, por referencia a dependientes "a honorarios" en el ámbito médico.

${ }^{26}$ En la tradición francesa de la responsabilidad pública esta calificación trae como consecuencia la irresponsabilidad del agente autor de la falta de servicio. Esa irresponsabilidad se muestra en la incompetencia de los tribunales civiles para conocer del asunto y en una acción de repetición contra el Estado, en caso de condena (impropia) contra el funcionario; para una aplicación relativamente reciente, v. Conseil d'Etat, 12 de abril de 2002, Papon, Recueil Lebon, 2002, p. 139 y ss. En definitiva, la responsabilidad por falta de servicio en este campo solo debería recaer sobre la administración, sin que quepa dirigirse la acción, conjunta ni alternativamente, contra el prestador contractual. Ahora bien, la jurisprudencia chilena nunca ha llegado al extremo de reconocer esa irresponsabilidad del agente público. $C f r$. los desarrollos sobre la responsabilidad civil del funcionario en VALDIVIA, José Miguel, "Derecho administrativo", Revista de Derecho de la U. Adolfo Ibáñez, 2016, № 4, p. 622 y ss. para un comentario sobre Corte Suprema, 24 de junio de 2011, Rol N 5.884-2008.
} 
esta cuestión de modo afirmativo, disponiendo que "el Estado no puede desvincularse de la falta personal en que ha incurrido su agente, ni siquiera bajo pretexto de serlo a honorarios", ${ }^{27}$ cuando esta falta personal no aparece desprovista de todo vínculo con el servicio. ${ }^{28} \mathrm{El}$ caso es particularmente importante, porque se trata de una falta personal de carácter delictual (por la cual el agente fue condenado penalmente por un delito de estafa en perjuicio de más de cien víctimas). La absorción de esta responsabilidad por la Municipalidad de Talcahuano se justifica especialmente en razón de la apariencia: el agente recibía a las víctimas en las oficinas de la municipalidad, les otorgaba recibos o certificados con estampados de la misma y se trasladaba en un vehículo que portaba el logotipo del organismo.

¿Es relevante la vigilancia del servicio sobre el prestador? Sin duda, las condiciones espaciales, temporales y materiales de prestación de sus servicios hacen plausible que estos agentes estén sujetos a supervisión estrecha por la administración. Sin embargo, así como una falta de vigilancia es irrelevante para dar por establecida la falta de servicio atribuible a hechos de los funcionarios, tampoco parece necesaria en este tipo de casos. Todos los agentes públicos, funcionarios o prestadores a honorarios, cuentan con márgenes de autonomía relativamente significativos en el desempeño de sus tareas, sin que sea concebible un control estrecho de la autoridad a su respecto. Basta con que las condiciones de funcionamiento del servicio hagan posible la culpa para que el Estado deba responder.

Aunque la jurisprudencia no ofrece ilustraciones, es posible pensar que soluciones análogas sean extensibles a la "externalización" de diversas actividades estatales, como la que la ley 18.803 admitió en relación a "las acciones de apoyo a sus funciones que no correspondan al ejercicio mismo de sus potestades" de los órganos públicos (art. 1). Así, para referir un ejemplo usual, en varias oficinas públicas las funciones de mantención del aseo de las instalaciones son cubiertas por empresas contratadas al efecto. En función de las circunstancias, la prestación de servicios puede traducirse en una actividad imbricada de modo permanente en la operación del organismo público. Sin perjuicio de una mayor rotación del personal que efectivamente

\footnotetext{
${ }^{27}$ Corte Suprema, 13 de junio de 2019, Rol N².238-2019 (cons. 6).

${ }^{28}$ Esta figura prolonga la jurisprudencia Morales Gamboa (Corte Suprema, 14 de enero de 2011, Rol $\mathrm{N}^{\circ}$ 7.919-2008), que, a su vez, replica el clásico régimen de la jurisprudencia Mimeur del derecho francés (Conseil d'Etat, 18 de noviembre de 1949, Recueil Lebon, 1949, p. 492 y ss.).
} 
cumple las tareas contratadas, estas condiciones de cumplimiento del contrato de servicios son del todo similares a aquellas en que funciona ordinariamente el servicio público (los prestadores ocupan instalaciones de la institución, desempeñan sus labores en horarios cercanos o idénticos a los de los funcionarios, por ejemplo). De este modo, la externalización puede ser entendida como una modalidad de organización del cumplimiento de las tareas propias del organismo público. Por eso, parecería difícil para el organismo excusarse de responsabilidad frente a actividades desarrolladas por el prestador del servicio en el cumplimiento de sus funciones; las culpas de este prestador en cumplimiento de sus tareas también pueden ser tenidas por faltas de servicio, en condiciones por completo similares a las que se analizaran a propósito de los contratos de servicios personales permanentes.

Aunque parezca discutible, puede preconizarse una solución similar con respecto a las culpas de estos prestadores desligadas del cumplimiento de sus tareas. Tratándose de las faltas personales de los funcionarios, la responsabilidad del Estado parecería justificarse no tanto en razón de una falta de servicio implícita -como una culpa in eligendo o in vigilando-sino por exponer a terceros o a su propio personal a un tipo singular de riesgos. ${ }^{29}$ Esa explicación es extensible a situaciones similares, como las que aquí se analizan.

\subsection{Contratos de servicios esporádicos}

Los contratos de servicio pueden dar origen a prestaciones aisladas, que no pueden asimilarse a las que cumple ordinariamente el personal administrativo y, por lo tanto, la eventual responsabilidad de la administración ha de analizarse sobre la base de otros fundamentos. En este tipo de casos las circunstancias son determinantes para apreciar si la culpa del prestador puede arrastrar la responsabilidad del Estado (a lo menos, en función de los

${ }^{29}$ Tal es la explicación dada por Marcel WaLine para la cobertura estatal de las faltas personales no desprovistas de todo vínculo con el servicio. Comentando el fallo Sadoudi (Conseil d'Etat, 26 de octubre de 1973, Recueil Lebon, 1973, p. 603 y ss.), WALINE entendía que afirmaba que "la posibilidad de tal falta personal constituía un riesgo que [la administración] misma había creado... y ella debe garantizar a las víctimas en caso de realización del riesgo" (Nota publicada en Waline, Marcel, "Note", Revue du Droit Public, París, 1974, pp. 554 y ss., reproducida en Notes d'arrêts de Marcel Waline, París: Dalloz, 2005, t. II, p. 303 y ss.). La generalidad de este razonamiento rebasa el planteamiento inicial del fallo Sadoudi, relativo a "los peligros que, frente a terceros, resultan de la obligación impuesta a los [policías] de París de conservar un arma de fuego fuera del servicio". 
grados de autonomía del contratante o, correlativamente, de control de la administración sobre él).

El caso Pino Barra entrega un ejemplo de este tipo de contratos. Se perseguía la responsabilidad del Estado a raíz de la muerte y lesiones de un grupo de funcionarios, provocadas en un accidente de tránsito causado por un subcontratista de un organismo público que conducía a las víctimas luego de una jornada de capacitación profesional organizada por la institución. ${ }^{30}$ El daño había sido causado con ocasión de la ejecución de un contrato de transportes, que puede mirarse como un tipo específico de contrato de servicios. En el caso, para cumplir su obligación principal el contratista recurrió a un subcontratista. La Corte Suprema pone de relieve que, por la premura de la contratación, el organismo contratante no fiscalizó bien a su contratista - permitiendo así que la prestación fuera asumida por un tercero, sin reunir los requisitos de calidad exigidos contractualmente-, lo que configura una falta de servicio. Pero la Corte también toma nota del carácter obligatorio de la situación en que se vieron envueltas las víctimas con sus victimarios. Aunque este último argumento podría entenderse como una derivación de la idea de riesgo creado (dado que el traslado forzoso expuso a las víctimas al accidente), la Corte no se aparta del sistema de la falta de servicio, y el planteamiento se presenta más bien como un dato contextual que sugiere que esta culpa se produce en la gestión doméstica del servicio público. Así, la Corte parece reforzar la justificación de la absorción del accidente por la institución administrativa. En verdad, esta solución no sería para nada ortodoxa si, en un contexto similar, las víctimas fueran simples terceros, como otros automovilistas. ¿Debería en tal caso responder el Estado?

A pesar de lo reducido de esta muestra, parece consistente con los principios mejor establecidos que, tratándose de servicios ocasionales, la administración sólo responde por las culpas de sus proveedores si puede imputársele una falta de servicio propia.

\section{Contratos de intercambio para la obtención de un resultado}

La administración puede recurrir al mercado para obtener insumos

\footnotetext{
${ }^{30}$ Corte Suprema, 25 de mayo de 2017, Rol N 55.177-2016. Otro caso relativamente similar en Corte Suprema, 15 de julio de 2020, Rol N²4.390-2020.
} 
que requerirá en la ejecución de sus tareas. Desde luego, puede hacerlo bajo la forma de prestación de servicios, o sencillamente mediante la compra.

Tratándose de servicios, su singularidad recibe en que la prestación se desarrolla, por lo esencial, fuera de la esfera de control del prestatario. Varios tipos de prestaciones profesionales pueden caber en esta categoría, como ocurre con los estudios o informes técnicos, e incluso los dictámenes o informes jurídicos. En estos casos hay muy poca chance de que la prestación de servicios irrogue perjuicios al personal de la administración o a sus usuarios, atendidas las condiciones en que se llevan a cabo las prestaciones. Es el contratista mismo quien debe hacer frente a las contingencias que resulten de su actividad, sin que el Estado deba participar en la reparación, a menos de que se demuestre una falta de servicio propia, por ejemplo, consistente en instrucciones (inapropiadas o erróneas) que hubiera impartido al prestador.

Ahora bien, una vez concluidos los servicios y recibidos los "productos" por la administración, el uso que esta pueda darles es de su propia responsabilidad, sin perjuicio de su eventual derecho a repetir en contra del prestador. El paradigma de estas figuras es el contrato de construcción de obras públicas u otros inmuebles, que se analiza en la sección siguiente; pero ahí los servicios se prestan bajo un control intenso de la administración y usualmente en recintos de su propiedad. Cabe referirse previamente al contrato de suministro.

\subsection{Contratos de suministro}

El contrato de suministro tiene por objeto la provisión de bienes muebles a la administración. Normalmente supone una compraventa, ya sea que implique una o más entregas espaciadas en el tiempo. Conforme a su definición legal en el derecho chileno, también cubre el arrendamiento de ese tipo de bienes, con opción de compra o sin ella. ${ }^{31}$

Es difícil imaginar que los proveedores provoquen, con ocasión del cumplimiento de sus obligaciones contractuales, daños de los que se pretenda que la administración responda. Es bastante evidente que las actuaciones del vendedor en la elaboración o la adquisición de las cosas vendidas se sitúan

${ }^{31}$ Ley $\mathrm{N}^{\circ} 19.886$, de bases sobre contratos administrativos de suministro y prestación de servicios, 2003, art. 2 . 
dentro de su exclusivo ámbito de control y riesgos, respecto del cual cuenta con la más amplia autonomía.

Salvo en la fase de la entrega de las cosas, la provisión de bienes no implica necesariamente una prestación de servicios, con ocasión de los cuales los contratantes de la administración puedan interactuar con administrados o agentes públicos. Ahora bien, si el suministro supone, además, una prestación de servicios, habría de aplicarse criterios similares a los que rigen en materia de contratos de servicios.

En todo caso, una vez entregadas las cosas de que se trata, la administración las incorpora a sus procesos, de modo que los eventuales daños que se generen a raíz de su utilización solo podrían ser cubiertas por la administración en tanto se acredite la comisión de una falta de servicio. Por cierto, en tanto el proveedor sea identificado o identificable (por ejemplo, el fabricante de productos defectuosos), no hay que excluir que la víctima también pueda enderezar sus acciones en su contra.

La experiencia chilena es muy limitada en este campo. Puede referirse el reciente caso Ticona Tarapa, que surge en el contexto de un contrato de suministro alimenticio dedicado a los estudiantes de un establecimiento educacional municipal (celebrado por la Junta de Auxilio Escolar y Becas en el marco de su programa de alimentación escolar). ${ }^{32}$ Se trata de un caso especial, porque el suministro implica la entrega directa de los bienes a los usuarios de un servicio público; es decir, el contrato conlleva una relación de servicios, que además cede en beneficio de terceros distintos de la administración.

En virtud del contrato el proveedor debía disponer de cierta infraestructura para facilitar la entrega de los almuerzos a los usuarios; el accidente se produjo a raíz del mal estado de sustentación de esa infraestructura, sobre la que estaba apoyado un recipiente de agua caliente que cayó sobre uno de los niños usuarios del servicio, provocándole quemaduras mortales.

Dando muestras de no estar muy dispuesta a admitir que en este campo el Estado se libere de su responsabilidad, la Corte Suprema estima suficiente para dar por establecida la falta de servicio el que el organismo demandado "gozaba de atribuciones y más aún, le asistía la obligación para tomar las medidas de seguridad tendientes a que la prestación del servicio

${ }^{32}$ Corte Suprema, 6 de julio de 2017, Rol N 100.620-2016. 
de alimentación que se le ha encomendado por ley no resulta riesgosa para los alumnos a los cuales está dirigida, exigencia legal que no fue cumplida".

Con todo, aunque la consideración transcrita es elocuente, la falta de servicio no se deduce mecánicamente de la sola titularidad de un poder de vigilancia. En verdad, no era difícil constatar un defecto de vigilancia de la administración sobre su proveedor; las circunstancias facilitaban una revisión continua de su gestión, pues los servicios se prestaban al interior de un recinto público, que sirve de sede a un establecimiento educativo. Además, la Corte Suprema llama la atención sobre el hecho de que el director del colegio había advertido a la Junta acerca del mal estado de esa estructura metálica.

\subsection{Contratos de construcción ${ }^{33}$}

La ejecución de contratos de construcción de obras públicas u otros inmuebles suele ser un factor de riesgo de accidentes, tanto para el personal que trabaja en la obra como para víctimas ajenas a ella. ${ }^{34}$ La ocurrencia de daños se hace posible por la prolongación de los trabajos, el uso de maquinaria más o menos pesada y la situación espacial de las obras, frecuentemente en áreas de fácil acceso por el público.

Conforme a la teoría clásica del contrato administrativo -que halla en este contrato una de sus mejores ilustraciones- la administración conserva importantes poderes de dirección y control sobre el contratista. ${ }^{35}$ Los textos normativos prevén la presencia permanente de un personero de la administración en las obras, lo que es la muestra más categórica de esos poderes, que se traducen en cierto predominio de la administración en

\footnotetext{
${ }^{33}$ Esta materia ha sido analizada con mayor detención en VALDivia, José Miguel, "Sobre la responsabilidad extracontractual de la administración por daños provocados por sus contrapartes en contratos de construcción en el Derecho chileno", en Alcaraz, H.; Vergara, A. (Eds.), Itinerario latinoamericano del derecho público francés. Homenaje al profesor Franck Moderne, Tirant lo Blanch, Valencia, 2019, p. 539 y ss. Este párrafo resume las principales orientaciones detectadas con ocasión de ese estudio.

${ }^{34}$ Eventualmente, los daños también pueden alcanzar a terceros beneficiarios de la obra en construcción, en el marco de actividades constructivas de servicio público, como la edificación de viviendas sociales. $C f$. Corte Suprema, 20 de enero de 2012, Rol N 4.806-2009.

${ }^{35}$ En una de las principales monografías sobre la ejecución del contrato de obras se afirma que el poder de dirección de la obra se traduce en dos funciones típicas: la interpretación del proyecto y el control de la ejecución de la obra. JURISTO, Rafael, "La ejecución del contrato de obra pública", Tesis Doctoral, Universidad Complutense de Madrid, España, 1983, p. 125 y ss.
} 
cuanto dueño de la obra. ${ }^{36}$

En su tratamiento jurisprudencial, la responsabilidad del Estado a raíz de daños causados por el contratista tiene un carácter expansivo, que parece obedecer a dos categorías de fundamentos.

\section{i) Responsabilidad con fundamento en faltas de vigilancia}

Algunos fallos imputan a la administración defectos de vigilancia o supervisión respecto de sus contratistas.

Es, para citar un ejemplo entre varios, el caso de Torres González, relativo a un accidente del trabajo. Durante la ejecución de unas obras viales, un trabajador del contratista, conductor de un camión de alto tonelaje, fallece en un accidente de tránsito al quedar dormido al volante. Se estimó que la causa del accidente fue la falta de descanso del conductor, debida a la realización de trabajos nocturnos no autorizados. Aplicando la legislación laboral en materia de subcontratación, la Corte Suprema condenó al Fisco por haber faltado "a su deber de fiscalización respecto de las condiciones en las que se desarrollaban las labores relacionadas con el proyecto de construcción de una obra pública..., pues no verificó que se cumplieran las más elementales obligaciones de carácter laboral". ${ }^{37}$

Conceptualmente, la responsabilidad es aquí fruto de una falta de servicio independiente de la culpa del contratista. Con todo, para dar por establecida esa falta de servicio la jurisprudencia solo toma en cuenta los poderes de control de la administración contratante, ${ }^{38}$ sin especificar muy bien aquello que la administración hubiera podido hacer para evitar el accidente, atendidas las circunstancias, la información disponible y los medios de acción de la administración.

Por eso, en términos prácticos, todo indica que esta especie de culpa in vigilando se construye a partir de la simple materialización de los

\footnotetext{
${ }^{36} \mathrm{El}$ inspector fiscal está concebido como "el funcionario profesional que, nombrado en forma competente, asume el derecho y la obligación de fiscalizar la correcta ejecución de las obras y el fiel cumplimiento de un contrato de construcción": Decreto Supremo $\mathrm{N}^{\circ} 75$, del Ministerio de Obras Públicas, que aprueba reglamento para contratos de obras públicas, 2004, art. $4 \mathrm{~N}^{\circ} 9$.

${ }^{37}$ Corte Suprema, 21 de agosto de 2017, Rol N 92.863-2016 (sentencia de reemplazo, cons. 11).

${ }^{38}$ La jurisprudencia se conforma con constatar la existencia de estas potestades, como si ellas proporcionaran un marco justificativo de las obligaciones de seguridad para con los trabajadores y eventualmente también para con el público. Sin embargo, el tratamiento dogmático de estos poderes subraya su relevancia funcional para la buena ejecución de la obra; $c f$. LAUBADĖRE, MODERNE y DelVOLVÉ, cit. (n. 16), t. II, p. 441 y ss., JuRISTO, cit. (n. 35), p. 129.
} 
daños provocados por hecho o culpa del constructor. La jurisprudencia ha descartado que esta vinculación casi automática entre culpa del contratista y falta de servicio por defecto de vigilancia constituya un caso responsabilidad estricta. ${ }^{39}$ Luego, para una explicación del mecanismo consistente con el régimen legal, cabría pensar que la falta de servicio es presumida a partir del daño causado por hecho o culpa del constructor y sus dependientes. Consistentemente, es teóricamente admisible que la administración se exonere de responsabilidad demostrando actos suficientes de fiscalización de sus contratistas (aunque esta circunstancia sólo se ha aceptado de modo excepcional). ${ }^{40}$

\section{ii) Responsabilidad con fundamento en los deberes de conservación de las vías públicas}

Paralelamente, la jurisprudencia enfrenta estos casos recurriendo al mecanismo corriente de responsabilidad por accidentes de vialidad, cuando esta se persigue con fundamento en el incumplimiento de la obligación de señalizar los desperfectos o anomalías que se situaren en las vías públicas.

Cabe tener presente que una regla expresa prevé la responsabilidad solidaria de quien ejecute trabajos en las vías públicas y quien encargue su ejecución, por el incumplimiento de los deberes de señalizar o tomar precauciones adecuadas, y de reparar las vías una vez concluidos los trabajos. ${ }^{41}$ Sin embargo, esta regla rara vez es invocada por las víctimas, quienes confían más en el régimen general de responsabilidad pública sobre accidentes en las vías públicas. ${ }^{42}$

${ }^{39}$ Corte de Apelaciones de Concepción, 1 de diciembre de 2016, Rol N ${ }^{\circ}$ 526-2016.

${ }^{40}$ Así, p. ej., Corte Suprema, 5 de noviembre de 2013, Rol N 9.163-2012. Adviértase que el contrato en cuestión es una concesión de obra pública, pero los daños se producen durante la construcción de las obras concesionadas.

${ }^{41}$ Ley de Tránsito (DFL N ${ }^{\circ} 1$, del Ministerio de Transportes y Telecomunicaciones, que fija texto refundido, coordinado y sistematizado de la Ley de Tránsito, 2009), art. 96, incs. 1 y 2: "El que ejecute trabajos en las vías públicas, estará obligado a colocar y mantener por su cuenta, de día y de noche, la señalización que corresponda y tomar medidas de seguridad adecuadas a la naturaleza de los trabajos, conforme al Manual de Señalización de Tránsito. Deberá, además, dejar reparadas dichas vías en las mismas condiciones en que se encuentre el área circundante, retirando, de inmediato y en la medida que se vayan terminando los trabajos, las señalizaciones, materiales y desechos. / Serán solidariamente responsables de los daños producidos en accidentes por incumplimiento de lo dispuesto en el inciso anterior, quienes encarguen la ejecución de la obra y los que la ejecuten". Adviértase que el inciso final del precepto dispone: "Lo dispuesto en el presente artículo no obsta a la reglamentación que sobre trabajos en la vía pública o sobre ruptura o reposición de pavimentos dicten las Municipalidades".

${ }^{42}$ No es claro, ni parece haberse explorado en la jurisprudencia, que en razón de su generalidad, esta 
Como se sabe, el artículo 169 de la Ley de Tránsito hace responsables a la municipalidad respectiva o al Fisco "de los daños que se causaren con ocasión de un accidente que sea consecuencia del mal estado de las vías públicas o de su falta o inadecuada señalización". Atendida su amplitud, esta fórmula legal comprende los déficits de señalización de todo tipo de eventos provenientes de la ejecución de contratos de construcción sobre las vías públicas, aunque por cierto no se limita a esos casos. ${ }^{43}$

Para un ejemplo, en Taucare Améstica una municipalidad es condenada por los daños provenientes de la caída de un poste del alumbrado público sobre un vehículo que había ingresado a una calle en cuya acera se efectuaban trabajos por una empresa contratista. La falta de servicio de la municipalidad se entiende configurada, con fundamento en sus deberes de señalización vial, porque "no adoptó medidas de seguridad tendientes a evitar accidentes consistentes por una parte en la colocación de una debida señalética o haber fiscalizado que ésta estuviera en el lugar y por otra, debió haberse preocupado por el buen estado de los postes de alumbrado público". ${ }^{44}$

La extensión de este régimen de responsabilidad a los casos de accidentes provocados por la realización de trabajos ejecutados por contratistas es posible, como se ha dicho, en razón de la amplitud del texto legal que lo consagra. En la medida que se refiere indistintamente al mal estado de las vías y a la falta o inadecuada señalización, se remite prácticamente a todos los riesgos que son susceptibles de encontrarse en las vías públicas. El deber general de señalización vial que pesa sobre la administración ${ }^{45}$ tiene un campo de acción comprensivo de todo tipo de evento singular o anormal, y a fortiori de aquellos que provengan de operaciones programadas con antelación, en el marco de contratos de obras. Por otra parte, la jurisprudencia ha entendido que los deberes municipales

regla deba ser desplazada por la norma especial del artículo 96 (en nota anterior).

${ }^{43} \mathrm{Al}$ contrario, la responsabilidad procede aunque los organismos públicos demandados no tengan relación con los trabajos que se ejecuten sobre las vías públicas, sea que las obras sean ejecutadas por cuenta de organismos públicos distintos o incluso por cuenta de privados cuya infraestructura esté instalada en vías públicas. Cfr. VAldivia, "Sobre la responsabilidad extracontractual de la administración...", cit. (n. 32), p. 548.

${ }^{44}$ Corte de Apelaciones de Antofagasta, 13 de agosto de 2013, Rol No 409-2013 (cons. 12), conf. Corte Suprema, 5 de noviembre de 2013, Rol № 8.132-2013. Un caso relativamente similar en Corte Suprema, 29 de enero de 2020, Rol N²2.101-2018.

${ }^{45}$ Ley de Tránsito, art. 100. 
relativos a la vialidad se justifican en obligaciones más amplias que derivan de la administración de los bienes del patrimonio público. ${ }^{46}$ De aquí que quepa incluir en estos deberes (y extenderles un régimen de responsabilidad comparable), aquellos inherentes a las operaciones contractuales de conservación de las vías públicas, y que se traducen en planificarlas, diseñar el contrato, dirigir las obras y controlar el cumplimiento de las obligaciones del contratista. ${ }^{47}$

\section{iii) Una observación a estas hipótesis}

Es llamativo que en las dos vertientes que asume la responsabilidad en este tipo de casos se prescinda por completo de la culpa del contratista. Este factor parece irrelevante para la jurisprudencia, lo que sugiere que su invocación por la administración como excusa (susceptible de calificarse como hecho de un tercero) no habría de ser tomada en cuenta. Así, asumiendo teóricamente que la víctima puede dirigirse siempre contra el contratista, autor inmediato del hecho dañoso, estas orientaciones jurisprudenciales equivalen a consagrar un derecho de opción, de modo que la víctima escoja libremente el patrimonio en contra del cual pretende hacer efectiva la reparación. ${ }^{48}$ Considerando, por otra parte, que la condena indemnizatoria que pueda recaer sobre la administración no impide repetir ese pago contra el contratista, concurren en esta responsabilidad los rasgos de una solidaridad imperfecta. ${ }^{49}$

\subsection{Contratos de concesión}

La lógica parece ser distinta tratándose de los contratos de concesión.

La singularidad de estos contratos proviene del régimen de gestión del servicio público a que dan origen, por largo tiempo considerado como una

\footnotetext{
${ }^{46}$ Entre muchos otros, v. últimamente, Corte Suprema, 20 de septiembre de 2017, Rol № 5.813-2017.

${ }^{47} C f$., en este sentido, Corte Suprema, 2 de septiembre de 2015, Rol № 2.838-2015.

${ }^{48}$ Derecho de opción coincidente con la perspectiva francesa adoptada sobre la misma materia. $C f$. Chapus, René, Droit administratif général, Montchrestien, París, 2000, 14ª ed., T. I, p. 1257.

${ }^{49}$ Esta calificación como “obligación in solidum”, según la terminología francesa, proviene de la condena al total de la indemnización, sumada a la (potencial, pero bastante segura) acción de repetición de la administración contra su coobligado. $C f$. MoDERnE, Franck, "Recherches sur l'obligation in solidum dans la jurisprudence administrative", Etudes et Documents du Conseil d'Etat, 1973, p. y 15 s.
} 
modalidad particular de administración de la cosa pública. ${ }^{50}$ En razón de su objeto, estos contratos pueden concebirse como aquellos mediante los cuales la administración (concedente) entrega a algún particular (concesionario) la gestión de un servicio público; el concesionario, a su vez, asume por su cuenta y riesgo la obligación de prestar el servicio al público en las condiciones legales y reglamentarias que lo rijan y, en contrapartida, se remunera con los resultados de la explotación de ese servicio (por lo común, en función de una tarifa determinada). ${ }^{51}$ En buenas cuentas -y es en este aspecto que se aprecia su mayor diferencia con los contratos de intercambio- el concesionario no entrega nada al Estado, aunque lo descarga de sus tareas al asumir las directamente frente al público; simétricamente, por principio el Estado tampoco paga al concesionario, aunque al hacerse sustituir por éste, también lo habilita a percibir una remuneración de los usuarios o en consideración a ellos. Durante la vigencia de la concesión, el concedente conserva una titularidad teórica respecto de la actividad concesionada, pero en la práctica el gestor de la actividad de servicio público es el concesionario. ${ }^{52}$ El tipo de negocio que representa la concesión lleva consigo un grado importante de autonomía de gestión para el concesionario, lo que se traduce en una dirección y supervisión atenuadas por parte de la autoridad concedente.

La teoría distingue entre concesiones de servicio público y concesiones de obra pública (que también envuelven, total o parcialmente, la del servicio a que está afecto la obra).$^{53}$ En general, el modelo básico es la concesión de servicio público, pero ésta puede implicar para el concesionario la carga de conservar o ejecutar obras públicas que, al término del contrato, se radiquen

\footnotetext{
${ }^{50}$ El contrato (de delegación de servicio público, género al que pertenece la concesión) "no es solo contrato: es ante todo un modo de gestión de las actividades de interés general que toman a su cargo los entes públicos": Plessix, Benoît, Droit administratif général, Lexis Nexis, París, 2018, 2ª ed., p. 1161.

${ }^{51}$ Para una caracterización de la concesión, v. Soто KLoss, Eduardo, "La concesión de servicio público. Notas para una precisión conceptual en el derecho chileno", Ius Publicum, 2002, № 9, p. 111 y ss., y ahora en su Derecho administrativo. Temas fundamentales (Santiago: Legal Publishing, 2009), p. 477 y ss.

52 “El objeto perseguido por la persona pública 'delegante' es precisamente no encargarse ella misma de actividades que ocupan, de un modo que se estima inoportuno, sus medios de acción, lo que supone que el cocontratante 'delegatario' sea libre de sus movimientos y decisiones...", afirman Gilles Guglielmi y Geneviève Koubi. Guglielmi, Gilles; Koubi, Geneviève, Droit du service public, Montchrestien, París, 2007, $2^{\text {a }}$ ed., p. 398.

${ }^{53}$ En este sentido, últimamente, Loo, Martín, “Las concesiones de obra pública: ¿qué son y por qué se utilizan en Chile?”, Revista Derecho del Estado, 2019, № 44, p. 343.
} 
en las manos del concedente. Esta distinción tiene alguna relevancia en el derecho chileno, porque mientras las concesiones de servicio público carecen de regulación general (y su estatuto se construye sobre la base de la teoría y de algunas normas especiales), las concesiones de obra pública de mayor relevancia, que son aquellas que lleva adelante el Ministerio de Obras Públicas, ${ }^{54}$ están sujetas a un régimen legal relativamente conocido, previsto por la ley de concesiones de obras públicas. ${ }^{55}$

\section{i) Responsabilidad y concesiones}

La doctrina clásica de la concesión asume que es el concesionario quien hace frente a las responsabilidades que deriven de la gestión del servicio público de que se trata, es decir, de las que provengan de la explotación del servicio por su cuenta, incluidas las que surjan de las obras que eventualmente el concesionario esté llamado a conservar o construir. En cambio, la teoría afirma que el concedente sólo queda sujeto a una responsabilidad subsidiaria, prevista para el caso de insolvencia del concesionario. ${ }^{56}$

En tal sentido, puede referirse la más tradicional doctrina chilena, resumida por Enrique Silva: en tanto "las relaciones entre el concesionario de un servicio público y los particulares se encuentran plenamente sometidas al Derecho Común... el particular tiene acción directa ante los tribunales para recurrir de indemnización de perjuicios en contra del concesionario que con la acción culposa de su servicio, o con su inacción, es decir, cuando debiendo prestar el servicio no lo hace, ha causado un daño en el patrimonio de ese particular". ${ }^{57}$

El reconocimiento positivo de estas nociones se ha traducido en una

${ }^{54}$ Esta ley no se extiende a las concesiones de obra pública que se ideen por organismos públicos distintos; por ejemplo, no están sujetas a sus prescripciones las concesiones municipales que se construyan en el subsuelo de calles y plazas (usualmente para la operación de estacionamientos), no obstante su identidad sustantiva con las concesiones ministeriales. Con todo, aquellas operaciones celebradas bajo la forma de contratos de financiamiento urbano compartido, regidas por la Ley $\mathrm{N}^{\circ}$ 19.865, quedan sujetas a disposiciones similares.

${ }^{55}$ DFL N $^{\circ} 900$, del Ministerio de Obras Públicas, que fija el texto refundido, coordinado y sistematizado del DFL MOP N¹64, de 1991 Ley de Concesiones de Obras Públicas, 1996.

${ }^{56}$ Los concesionarios o delegatarios de la actividad dañosa, que "se consideran como sustituidos a la persona pública con respecto a las víctimas, sólo son responsables a título principal. La responsabilidad incumbe, en efecto, a título subsidiario, a la persona pública en caso de insolvencia del delegatario", sostiene CHAPUS, cit. (n. 48), p. 1256.

${ }^{57}$ Silva Cimma, Enrique, Derecho administrativo chileno y comparado, T. IV, El servicio público, Editorial Jurídica de Chile, Santiago, 1995, p. 265. 
regla explícita de responsabilidad del concesionario contenida en la ley de concesiones de obra pública, aunque no existe igual claridad respecto de las demás concesiones.

\section{ii) Concesión de obra pública}

El artículo 35 de la Ley de concesiones de obra pública dispone: "El concesionario responderá de los daños, de cualquier naturaleza, que con motivo de la ejecución de la obra o de la explotación de la misma se ocasionaren a terceros, a menos que sean exclusivamente imputables a medidas impuestas por el Ministerio de Obras Públicas, después de haber sido adjudicado el contrato". ${ }^{58}$ Prima facie, pues, el concesionario es el responsable primario de los daños causados durante la explotación de la concesión; inversamente, el Estado concedente no es llamado a responder en tales supuestos.

La aplicación práctica de esta regla ha dado origen a varias preguntas relevantes para determinar la responsabilidad de los concesionarios de obra pública, que exceden del ámbito de interés de este trabajo. ${ }^{59}$ Ahora bien, en cuanto respecta a la eventual responsabilidad del concedente, la jurisprudencia de juzgados y cortes de apelaciones ha sido zigzagueante, ${ }^{60}$

\footnotetext{
${ }^{58}$ Norma análoga contempla el art. 20 de la Ley $\mathrm{N}^{\circ} 19.865$ para los contratos de financiamiento urbano compartido.

${ }^{59}$ Para la literatura nacional, v., entre otros, Alarcón, Pablo, "Comentario Jurisprudencial. Solidaridad en el pago de indemnización de perjuicios por Responsabilidad del Estado y de Sociedad Concesionaria en accidente en vía concesionada (autopista)", en Arancibia, J.; MARTínez, J.I; Romero, A. (Eds.), Litigación pública, Abeledo Perrot, Santiago, 2011, pp. 323 y ss., Diøz, José Luis, "La responsabilidad civil del concesionario de obras viales y su fundamento en la obligación de seguridad respecto de los usuarios en el Derecho chileno", Revista de Derecho P. Universidad Católica de Valparaíso, 2012, N 38, pp. 121 y ss., RomÁn, Cristián, "La responsabilidad del Estado por los daños sufridos por el usuario de una carretera concesionada, por inactividad administrativa en ejercicio de sus facultades de inspección y vigilancia", en Fernández, J.; SANTIAGo, J., (Coord.), Contencioso administrativo. Culturas y sistemas jurídicos comparados, U. Autónoma de México, México, 2007, p. 359 y ss., Román, Cristián, "Responsabilidad patrimonial de la administración del Estado y de su concesionario vial, frente al usuario lesionado", en FACULTAD DE DERECHO Universidad de Valparaíso (Eds.), XXXV Jornadas Chilenas de Derecho Público: El derecho público chileno y la globalización, Edeval, Valparaíso, 2006, p. 233 y ss., Viñuela, Mauricio, "La responsabilidad por falta de servicio en el contexto del régimen de concesiones viales vigentes en Chile", Ius Publicum, 2001, N 7, p. 35 y ss., y Viñuela, Mauricio, "La concesión de obras públicas en Chile: ¿Privatización de la responsabilidad del Estado en la empresa concesionaria?", Responsabilidad civil de entidades corporativas, Cuadernos de Extensión Jurídica (Universidad de los Andes), 2003, ํ7, p. 109 y ss.

${ }^{60}$ Las vacilaciones también alcanzaron a la Corte Suprema (Corte Suprema, 4 de diciembre de 2012, Rol N ${ }^{\circ}$ 6229-2010): "respecto de la responsabilidad del Fisco por las obras concesionadas, conviene tener presente que se ha afirmado que si se ha delegado en particulares la provisión de servicios que por ley corresponde a la Administración, ésta conserva una responsabilidad directa por el mal estado de las vías o una inadecuada
} 
lo que ha requerido la intervención de la Corte Suprema a fin de esclarecer las cosas. Finalmente, ésta ha hecho prevalecer la literalidad de la norma, resolviendo que "tratándose de los daños ocasionados a terceros con motivo de la explotación de la obra concesionada sólo existe responsabilidad estatal cuando los daños sean exclusivamente imputables a medidas impuestas por el Ministerio de Obras Públicas, después de haber sido adjudicado el contrato. Así, en el régimen de concesiones de obras públicas en Chile existe una norma explícita que consiste en que cuando el Estado ha delegado la provisión de servicio de una obra pública fiscal en cuanto a su explotación, ejecución, reparación o mantención en el sector privado, su responsabilidad indemnizatoria sólo surge cuando con motivo de su labor de fiscalización impone una medida que es la causante del daño, en cuyo caso el servicio prestado es deficiente. Debe tenerse presente que el propósito de la Ley de Concesiones de Obras Públicas radica en que el sujeto responsable sea el concesionario". ${ }^{61}$

\section{iii) Responsabilidad del concedente}

Con todo, la regla de responsabilidad antes transcrita no excluye el juego de eventuales responsabilidades del concedente, que serían procedentes en conformidad al derecho común de la responsabilidad pública. ${ }^{62} \mathrm{~A}$ este respecto, un importante fallo Vega Muñoz intenta sistematizar la responsabilidad del Fisco en estos casos, proponiendo la formulación de ("al menos") tres hipótesis: (i) "Por excepción, cuando con motivo de la ejecución o explotación de la obra fiscal concesionada se ocasionen daños a terceros por medidas exclusivamente impuestas por el Ministerio de Obras Públicas", en aplicación de la regla del artículo 35 de la ley de concesiones; (ii) "el Fisco responde por la ausencia de control y fiscalización de los deberes del concesionario", en razón de sus prerrogativas contractuales; y (iii) "el Fisco es responsable de los daños causados por deficiencias viales que derivan de la omisión" de los "deberes del planeamiento, estudio,

señalización, a condición de que la empresa concesionaria haya incurrido en una falta en la prestación del servicio que le ha sido delegado" (cons. 25); con todo, hay voto disidente del ministro Muñoz.

${ }^{61}$ Corte Suprema, 30 de enero de 2013, Rol No 216-2011 (cons. 14). En el mismo sentido, Corte Suprema, 13 de noviembre de 2017, Rol N 6.860-2017.

${ }^{62}$ A una conclusión similar llega el derecho francés. "Como es normal, el sistema [de la responsabilidad primaria del concesionario] no se aplica si el daño es imputable a faltas de la persona pública misma (por ejemplo, faltas en la supervisión ejercida sobre el particular)". CHAPUs, cit. (n. 48), p. 1257. 
proyección, construcción, mejoramiento y defensa de la obra pública fiscal en cuestión", de modo que debe hacerse cargo de las consecuencias que derivan del defecto de diseño del proyecto. ${ }^{63}$

El defecto del proyecto concesionado es precisamente el caso de Vega Muñoz. La Corte Suprema entendió que un puente caminero comprendido dentro de las obras concesionadas debía contar con medianas separadoras de las pistas, y que al no estar dispuesto así (apartándose del modelo del Manual de Carreteras), el Estado había incurrido en falta de servicio que comprometía directamente su responsabilidad.

Hasta ahora no se han conocido casos en que se impute exitosamente al concedente una culpa in vigilando respecto del concesionario. Teóricamente puede ocurrir que el Estado supervise de manera deficiente; con todo, dada la autonomía de gestión propia del concesionario, esa supervisión no puede ser muy intensa. ${ }^{64}$

\section{iv) Otras concesiones}

En el estado actual de la jurisprudencia, las soluciones son mucho más inciertas tratándose de otro tipo de concesiones.

En un caso Farías Salazar, se persigue la responsabilidad de una municipalidad por los daños sufridos por un trabajador de un concesionario de recolección de basura, con fundamento en las reglas del Código del Trabajo sobre trabajadores en régimen de subcontratación. La responsabilidad del municipio es establecida sobre la base del incumplimiento de deberes de fiscalización. ${ }^{65}$ La discusión de las partes no parece haber recaído sobre la singularidad de la concesión y el asunto se zanja como si el concesionario fuera un mero contratista. ${ }^{66}$

\footnotetext{
${ }^{63}$ Corte Suprema, 5 de noviembre de 2013, Rol ํ 4.292-2012 (cons. 15). Con menos espíritu sintético, estas tres hipótesis habían sido prefiguradas por la Corte en el recién citado fallo Gómez Zúniga de 30 de enero de 2013.

${ }^{64}$ La imputación de defectos de vigilancia se ha descartado por la Corte Suprema en los fallos Muñoz San Martín c/ Autopista Los Andes S.A. (1 de junio de 2012, cit.), Gómez Zúniga c/ Autopista del Sol (30 de enero de 2013, cit.), Ayala Álvarez c/ Sociedad Concesionaria Autopista Vespucio Sur S.A. (5 de noviembre de 2013, cit.); también por la Corte de Apelaciones de Concepción en Ortega Bobadilla c/ Fisco (1 de diciembre de 2016, cit.) y la Corte de Apelaciones de Valdivia en Llanquimán Cisternas c/ Ruta de los Ríos Sociedad Concesionaria S.A. (Corte de Apelaciones de Valdivia, 7 de febrero de 2017, Rol N 666-2016, conf. Corte Suprema, 26 de marzo de 2018, Rol N 18.287-2017).

${ }^{65}$ Corte Suprema, 24 de octubre de 2017, Rol No 8.364-2017.

${ }^{66}$ Otro caso aparentemente similar entrega una pista falsa. El fallo Santander Flores (citado en n. 1) alude a la responsabilidad de la administración por daños causados por sus contratistas y concesionarios,
} 
Esta solución es cuestionable, porque el concedente no puede ser estimado "empresa principal" (ni debe, por tanto, responder por hechos del contratista o el subcontratista). El modelo de negocio que va envuelto en la concesión supone la traslación al concesionario de los riesgos de la actividad de servicio público. Las obras o los servicios los explota el concesionario por su cuenta, y no "para" la administración. Por eso, cabe entender que la empresa principal es el concesionario. Así se desprende, en el campo de la concesión de obra pública, de una norma expresa que exime al Estado de las consecuencias derivadas de los contratos del concesionario. ${ }^{67}$

Como ha dicho la mejor doctrina a propósito de la concesión de servicio público, "la administración no tiene propiamente hablando, poder de dirección de la ejecución del contrato; es el concesionario quien es dueño de la explotación, es decir, de los medios de asegurar el funcionamiento del servicio". ${ }^{68}$ Teóricamente el concedente conserva poderes de control sobre la concesión, pero en este terreno su ejercicio debe adaptarse a la autonomía con que cuenta el concesionario. ${ }^{69}$ No es trivial que hasta ahora en los pocos casos en que esta cuestión se ha discutido la jurisprudencia haya descartado la responsabilidad de la administración concedente por insuficiente vigilancia de las condiciones laborales de los trabajadores supuestamente subcontratados. ${ }^{70}$ La solución de Farías Salazar es, entonces, una anomalía.

pero los hechos del caso dan cuenta de la ejecución del servicio de recolección de basuras directamente por la municipalidad, sin concesión de por medio.

${ }^{67}$ En una de las escasas precisiones acerca del "régimen jurídico de la concesión", la ley prevé que durante la fase de construcción, "las obras se efectuarán a entero riesgo del concesionario, incumbiéndole hacer frente a cuantos desembolsos fueren precisos hasta su total terminación... El Fisco no será responsable de las consecuencias derivadas de los contratos que celebre el concesionario con los constructores o suministradores..." (Ley de concesiones de obras públicas, art. 22, №2). Como se aprecia, la manera en que el derecho positivo reconoce la concesión supone que el concesionario reemplaza a la administración concedente, de modo que los trabajos que se ejecuten en las obras concesionadas solo repercuten sobre el patrimonio del concesionario. Es este quien debe ser tenido por dueño de la obra.

${ }^{68}$ Laubadère, Moderne y Delvolvé, cit. (n. 16), t. II, p. 425.

${ }^{69}$ La doctrina es categórica al respecto: “el criterio general de limitación del control [de la concesión] está dado por la noción de desnaturalización de la concesión; el control no debe conducir a transformar de hecho la concesión en una especie de explotación directa o de administración delegada... La elección de este modo de gestión que es la concesión significa precisamente que la administración ha querido, al confiar el servicio a un particular, dejar a su explotación una amplia autonomía... A pretexto de control, la administración no puede amarrar en realidad los poderes de iniciativa del concesionario de manera tal que éste no aparezca más que como un ejecutor, caso en el cual la concesión degeneraría en una administración delegada”. Laubadère, Moderne y Delvolvé, cit. (n. 16), t. II, p. 426.

${ }^{70}$ Así, los fallos Muñoz San Martín c/ Autopista Los Andes S.A. (Corte Suprema, 1 de junio de 2012, 
Tres otros casos se refieren a la responsabilidad de organismos público por hechos de supuestos concesionarios que, más bien, parecen meros proveedores.

En Gambotto Vargas se reconoce la responsabilidad del municipio a raíz de la caída de un árbol sobre una vivienda. La sentencia evoca una concesión para la mantención de áreas verdes y poda de árboles ornamentales en la comuna, pero en seguida descarta que el contrato tenga incidencia en la responsabilidad: "si bien resultó acreditado que la demandada licitó el servicio de mantención y poda de árboles, ello no la exime de su responsabilidad por las consecuencias dañosas que de dicha labor deriven, en tanto el aseo y ornato comunal es una obligación que el legislador ha puesto de cargo del municipio". ${ }^{71}$

A su vez, en los muy similares casos Herreros Nieto y Luengo Ojeda se declara responsables a dos municipios por los daños sufridos por transeúntes a raíz de golpes eléctricos provocados por postes del alumbrado público. Ante la excusa de las municipalidades de corresponder la mantención del alumbrado público a los "concesionarios" respectivos, la Corte Suprema desestima el argumento, pues "aun cuando el ente edilicio delegara en privados la prestación de un servicio que le correspondía desarrollar, no lo libera de su responsabilidad, toda vez que está obligado a exigir y fiscalizar que la actividad se realice adoptándose todas las medidas de seguridad". ${ }^{72}$

Estas soluciones no son consistentes con la lógica de las concesiones, lo cual probablemente se deba a que no son concesiones. El modo de retribución típico de la concesión es la tarifa, que se paga por o en consideración a cada usuario efectivo del servicio ${ }^{73}$ esta remuneración del concesionario da cuenta de los riesgos que éste asume, toda vez que sus ingresos son variables, mientras sus costos son fijos (o al menos, una parte importante, como el costo de la disponibilidad de las infraestructuras respectivas). Los riesgos en la concesión están distribuidos entre las partes de un modo consistente con la autonomía de gestión con que cuenta el concesionario. Los contratos

cit.) y Ayala Álvarez c/ Sociedad Concesionaria Autopista Vespucio Sur S.A. (Corte Suprema, 5 de noviembre de 2013, cit.).

${ }^{71}$ Corte Suprema, 20 de diciembre de 2017, Rol No 35.825-2017.

${ }^{72}$ Corte Suprema, 4 de septiembre de 2018, Rol No 1.015-2018 (cons. 11). En términos casi idénticos, Corte Suprema, 2 de agosto de 2018, Rol N 8.563-2018 (cons. 6).

${ }^{73} \mathrm{Sin}$ perjuicio de eventuales fuentes de financiamiento distintas, v. Blanquer, David, La concesión de servicio público, Tirant lo Blanch, Valencia, 2012, p. 1132 y ss. 
aquí analizados no siguen el modelo de distribución de riesgos propio de la concesión; es relativamente usual que en estos contratos el "concesionario" se remunere mediante un precio prestablecido (sea determinado como suma alzada por la totalidad de los servicios que se requieran, sea en función de precios unitarios que varían por tipos de servicio). Por lo demás, en ausencia de usuarios del servicio fácilmente identificables, el riesgo de demanda no puede existir. Más bien parece que los contratos analizados tengan simplemente por objeto la prestación de servicios.

En estos tres últimos casos es poco plausible que las víctimas conocieran exactamente la identidad del encargado de la gestión de las cosas que originan el daño; por eso, es razonable que el derecho les permita dirigirse contra el organismo público que aparece como titular de su administración. Por último, no se puede pasar por alto que los daños tienen por causa inmediata el estado de bienes integrantes del equipamiento público (árboles o postes), por lo que estos casos se asemejan bastante a los que ocurren cotidianamente en las calles por causa del mal estado de las vías públicas o la falta o inadecuada señalización de los eventos que se sitúen en ellas. De hecho, en Luengo y Herreros la Corte Suprema sostiene que el deber de vigilancia de los municipios emanaría de su deber de administrar los bienes nacionales de uso público y de señalizar adecuadamente las vías públicas ${ }^{74}$ en otras palabras, emplea una argumentación muy similar a la que suele servir de base justificativa al régimen de responsabilidad pública por accidentes de vialidad. Así, estas soluciones guardan estrecha similitud con las observadas en materia de contratos de construcción, aparentemente guiadas por el interés de ofrecer a la víctima las mayores chances de obtener indemnización, ampliando el círculo de posibles responsables.

\section{CONCLUSIONES}

Un examen atento a las distintas situaciones que se pueden presentar en la ejecución de contratos administrativos, tal como a nivel general hace la jurisprudencia, exige desconfiar del razonamiento de Santander Flores, con que se iniciara este estudio. Al contrario, buenas razones conducen a

${ }^{74}$ Corte Suprema, Rol 8.563-2018, cit. (cons. 7). En términos casi idénticos, Corte Suprema, Rol 1.0152018, cit. (cons. 12). 
consagrar regímenes diferenciados de responsabilidad en este plano.

Es muy poco clara la relevancia en el ámbito extracontractual de la categoría "contratistas y/o concesionarios" o, más abstractamente, contrapartes contractuales de la administración. La idea misma de que se trataría de una categoría uniforme es discutible, porque asume que la administración ocupa siempre un mismo tipo de posición frente a sus contratantes, cuando no es así.

Esta conclusión resulta pobre, porque se salda con una respuesta negativa. Sin duda, se pueden formular conclusiones más afirmativas, pero es muy complejo tratar de sintetizarlas.

El enfoque seguido en este trabajo permite identificar grosso modo cuatro categorías de regímenes. En los contratos de función pública (o equivalentes) la responsabilidad se comporta como si no hubiera contrato y los daños provinieren del personal administrativo. En los contratos de suministro o similares, incluyendo algunos contratos de servicios, la responsabilidad pareciera depender de una falta de servicio de vigilancia, las más de las veces presumida a partir de la mera titularidad de un poder de vigilancia o de inspección sobre el cocontratante. Este régimen también se extiende a los contratos de construcción, aunque con variantes cuando las obras ocupan la vialidad pública u otros espacios abiertos al público y se espera de la administración una vigilancia adaptada a los riesgos para los usuarios. Por último, en las concesiones prácticamente no tiene lugar la falta de vigilancia, en razón de la autonomía del concesionario, aunque pueden plantearse otras faltas de servicio relevantes, por ejemplo, en el diseño del contrato.

Desde luego, la falta de servicio es una constante indispensable para que el Estado responda por sus contrapartes, pero esta conclusión es tan elemental como trivial. Mirando más en profundidad, las soluciones parecen depender de la función que cumple cada contrato y la autonomía o control que en cada caso corresponde al cocontratante o a la administración, aunque no puede prescindirse de un examen atento a las circunstancias de cada caso. 


\section{BIBLIOGRAFÍA CITADA}

Alarcón, Pablo, "Comentario Jurisprudencial. Solidaridad en el pago de indemnización de perjuicios por Responsabilidad del Estado y de Sociedad Concesionaria en accidente en vía concesionada (autopista)", en ArANCIBIA, J.; Martínez, J.I; Romero, A. (Eds.), Litigación pública, Abeledo Perrot, Santiago, 2011.

BARROS, Enrique, Tratado de responsabilidad extracontractual, Editorial Jurídica de Chile, Santiago, 2006.

Blanquer, David, La concesión de servicio público, Tirant lo Blanch, Valencia, 2012.

Chabas, François, Cien años de responsabilidad civil en Francia, Van Dieren éditeur, París, 2004 (Trad. Mauricio TAPIA).

Chapus, René, Droit administratif général, Montchrestien, París, 2000, $14^{\mathrm{a}}$ ed., T. I.

Corral, Hernán, "Subcontratación y responsabilidad civil por accidentes del trabajo", 2014, El Mercurio Legal, en línea: https://www.elmercurio.com/ Legal/Noticias/Analisis-Juridico/2014/08/11/Subcontratacion-y-responsabilidadcivil-por-accidentes-del-trabajo.aspx, consultada: 24 de agosto de 2020.

De Laubadère, André; Moderne, Franck; Delvolvé, Pierre, Traité des Contrats Administratif, LGDJ, Paris, 1983, $2^{\mathrm{a}}$ éd., T. II.

Delvolvé, Pierre, "La responsabilité du fait d'autrui en droit administratif", en Université des sciences sociales de Toulouse (Eds.), Mélanges dédiés à Gabriel Marty, Presses de l'Université des Sciences Sociales de Toulouse, Toulouse, 1978.

Diez, José Luis, "La responsabilidad civil del concesionario de obras viales y su fundamento en la obligación de seguridad respecto de los usuarios en el Derecho chileno", Revista de Derecho P. Universidad Católica de Valparaíso, 2012, №38.

Guglielmi, Gilles; Koubi, Geneviève, Droit du service public, Montchrestien, París, 2007, $2^{\mathrm{a}}$ ed.

Hauriou, Maurice, Précis de droit administratif et de droit public, Sirey, París, 1933, 12 ed. (reimpreso por Dalloz en 2002).

JuRISTO, Rafael, "La ejecución del contrato de obra pública", Tesis Doctoral, Universidad Complutense de Madrid, España, 1983.

Loo, Martín, "Las concesiones de obra pública: ¿qué son y por qué se utilizan en Chile?", Revista Derecho del Estado, 2019, № 44.

Mendoza, Ramiro; Aguerrea, Pedro, "El contrato a honorarios dentro de la administración del Estado, bajo la luz dictaminante de la Contraloría General de la República”, en: Contraloría General de la República, La Contraloría General de la República y el estado de derecho. 75 años de vida institucional (1927-2002), Contraloría General de la República, Santiago, 2002.

Moderne, Franck, "Recherches sur l'obligation in solidum dans la 
jurisprudence administrative", Etudes et Documents du Conseil d'Etat, 1973.

Plessix, Benoît, Droit administratif général, Lexis Nexis, París, 2018, $2^{\mathrm{a}}$ ed.

RaJevic, Enrique, "La precarización del empleo público en Chile y el mito de la carrera funcionaria", Ponencia presentada en el $5^{\circ}$ Encuentro Anual de la Sociedad Chilena de Políticas Públicas, 2014, disponible en línea: http://www. academia.edu/5786149/La_precarización_del_empleo_público_en_Chile_y_el_ mito_de_la_carrera_funcionaria, consultada: 24 de agosto de 2020 .

RoMÁn, Cristián, "Responsabilidad patrimonial de la administración del Estado y de su concesionario vial, frente al usuario lesionado", en FACULTAD DE Derecho Universidad de Valparaíso (Eds.), XXXV Jornadas Chilenas de Derecho Público: El derecho público chileno y la globalización, Edeval, Valparaíso, 2006.

RomÁn, Cristián, "La responsabilidad del Estado por los daños sufridos por el usuario de una carretera concesionada, por inactividad administrativa en ejercicio de sus facultades de inspección y vigilancia”, en Fernández, J.; Santiago, J., (Coord.), Contencioso administrativo. Culturas y sistemas jurídicos comparados, U. Autónoma de México, México, 2007.

Silva Cimma, Enrique, Derecho administrativo chileno y comparado, T. IV, El servicio público, Editorial Jurídica de Chile, Santiago, 1995.

Sото Kloss, Eduardo, "La concesión de servicio público. Notas para una precisión conceptual en el derecho chileno", Ius Publicum, 2002, № 9.

VALDiviA, José Miguel, "Teoría del órgano y responsabilidad pública en la Ley de Bases de la Administración del Estado", Revista de Derecho (Valdivia), 2006, $\mathrm{N}^{\circ} 19$.

VAlDIVIA, José Miguel, "Derecho administrativo", Revista de Derecho de la U. Adolfo Ibáñez, 2015, № 4.

Valdivia, José Miguel, "Sobre la responsabilidad extracontractual de la administración por daños provocados por sus contrapartes en contratos de construcción en el Derecho chileno", en Alcaraz, H.; Vergara, A. (Eds.), Itinerario latinoamericano del derecho público francés. Homenaje al profesor Franck Moderne, Tirant lo Blanch, Valencia, 2019.

VIÑUELA, Mauricio, "La responsabilidad por falta de servicio en el contexto del régimen de concesiones viales vigentes en Chile", Ius Publicum, 2001, ํㅜ 7.

ViÑUELA, Mauricio, "La concesión de obras públicas en Chile: ¿Privatización de la responsabilidad del Estado en la empresa concesionaria?", Responsabilidad civil de entidades corporativas, Cuadernos de Extensión Jurídica (Universidad de los Andes), 2003, $\mathrm{N}^{\circ} 7$.

Waline, Marcel, "Note", Revue du Droit Public, 1974. 


\section{JURISPRUDENCIA CITADA}

Corte de Apelaciones de Antofagasta, 13 de agosto de 2013, Rol № 4092013.

Corte de Apelaciones de Concepción, 1 de diciembre de 2016, Rol N ${ }^{\circ} 526-$ 2016.

Corte de Apelaciones de Valdivia, 7 de febrero de 2017, Rol N 666-2016.

Corte Suprema, 30 de julio de 2009, Rol N 371-2008.

Corte Suprema, 19 de enero de 2010, Rol No 3.172-2008.

Corte Suprema, 14 de enero de 2011, Rol N 7.919-2008.

Corte Suprema, 24 de junio de 2011, Rol N 5.884-2008.

Corte Suprema, 20 de enero de 2012, Rol N 4.806-2009.

Corte Suprema, 1 de junio de 2012, Rol No 6.867-2011.

Corte Suprema, 4 de diciembre de 2012, Rol N 6.229-2010.

Corte Suprema, 28 de diciembre de 2012, Rol N 10.614-2011.

Corte Suprema, 30 de enero de 2013, Rol N² 216-2011.

Corte Suprema, 19 de junio de 2013, Rol №3.848-2012.

Corte Suprema, 5 de noviembre de 2013, Rol No 9.163-2012.

Corte Suprema, 5 de noviembre de 2013, Rol No 8.132-2013.

Corte Suprema, 2 de septiembre de 2015, Rol No 2.838-2015.

Corte Suprema, 12 de abril de 2016, Rol No 37.438-2015.

Corte Suprema, 22 de mayo de 2017, Rol N 4.860-2017.

Corte Suprema, 25 de mayo de 2017, Rol N 55.177-2016.

Corte Suprema, 6 de julio de 2017, Rol No 100.620-2016.

Corte Suprema, 21 de agosto de 2017, Rol N 92.863-2016.

Corte Suprema, 20 de septiembre de 2017, Rol N ${ }^{\circ}$ 5.813-2017.

Corte Suprema, 24 de octubre de 2017, Rol N 8.364-2017.

Corte Suprema, 13 de noviembre de 2017, Rol N ${ }^{\circ} 6.860-2017$.

Corte Suprema, 20 de diciembre de 2017, Rol N 35.825-2017.

Corte Suprema, 26 de marzo de 2018, Rol N 18.287-2017.

Corte Suprema, 2 de agosto de 2018, Rol No 8.563-2018.

Corte Suprema, 4 de septiembre de 2018, Rol No 1.015-2018.

Corte Suprema, 8 de abril de 2019, Rol N 5.393-2018.

Corte Suprema, 13 de junio de 2019, Rol N².238-2019.

Corte Suprema, 29 de enero de 2020, Rol No 22.101-2018.

Corte Suprema, 17 de abril de 2020, Rol N ${ }^{\circ} 24.675-2018$.

Corte Suprema, 15 de julio de 2020, Rol N² 24.390-2020.

Contraloría General de la República, 21 de enero de 2008, Dictamen $N^{\circ}$ 2.594 .

Conseil d'Etat, 18 de noviembre de 1949, Recueil Lebon, 1949, p. 492 y ss. Conseil d'Etat, 26 de octubre de 1973, Recueil Lebon, 1973, p. 603 y ss.

Conseil d'Etat, 12 de abril de 2002, Papon, Recueil Lebon, 2002, p. 139 y ss. 
NORMAS CITADAS

Ley $\mathrm{N}^{\circ} 19.865$, sobre financiamiento urbano compartido, 2003.

Ley $\mathrm{N}^{\circ} 19.886$, de bases sobre contratos administrativos de suministro y prestación de servicios, 2003.

DFL N ${ }^{\circ} 900$, del Ministerio de Obras Públicas, que fija el texto refundido, coordinado y sistematizado del DFL MOP N¹64, de 1991, Ley de Concesiones de Obras Públicas, 1996.

DFL $N^{\circ} 1$, del Ministerio de Transportes y Telecomunicaciones, que fija texto refundido, coordinado y sistematizado de la Ley de Tránsito, 2009.

Decreto Supremo $N^{\circ} 75$, del Ministerio de Obras Públicas, que aprueba reglamento para contratos de obras públicas, 2004. 